DOI: $10.29303 /$ jrpb.v8i1.168

ISSN 2301-8119, e-ISSN 2443-1354

Tersedia online di http://jrpb.unram.ac.id/

\title{
ANALISIS KESESUAIAN LAHAN TANAMAN PADI YANG BERKELANJUTAN DI KABUPATEN INDRAMAYU
}

\author{
Analysis of Suitability of Sustainable Paddy Field in Indramayu Regency
}

\author{
Khaerul Muttaqien*), Alexander Tunggul Sutan Haji, Akhmad Adi Sulianto \\ Jurusan Keteknikan Pertanian, Fakultas Teknologi Pertanian, Universitas Brawijaya, \\ Jl. Veteran, Malang 65145, Indonesia
}

Email ${ }^{*}$ : khaerulmuttaqien27@gmail.com

Diterima: Desember 2019

Disetujui: Februari 2020

\begin{abstract}
Indramayu Regency has an area of 209,942 ha consisting of 115,897 ha of paddy field, 56,937 ha of non-paddy field, and 37,108 ha of non-agricultural field. However, regarding the agricultural field use, farmers in Indramayu Regency still need direction in the right field use because of the behaviours of farmers who have not paid attention to land suitability and government policies on agricultural intensification. The method used in this study was the quantitative descriptive method and the process of matching the condition data of the region with land suitability class criteria compiled with Arc GIS 10.3. The parameters observed were the regional characteristics (climate, soil fertility and topography) and the criteria for sustainable agriculture (water availability) for paddy field. The purpose of this study was to determine the suitability of land and the sustainability of paddy field in Indramayu Regency. The results of the analysis of the suitability of sustainable paddy field in Indramayu Regency based on the determined criteria revealed that 92,419 ha, 7,654 ha, 15,824 ha and covered 0 fields were classified as very suitable (S1), quite suitable (S2), marginal fields (S3) and not suitable $(N)$, respectively.
\end{abstract}

Keywords: sustainability, soil fertility, water availability, rice

\begin{abstract}
ABSTRAK
Kabupaten Indramayu memiliki luas lahan 209.942 ha yang terdiri atas 115.897 ha lahan sawah, 56.937 ha lahan bukan sawah, dan 37.108 ha lahan bukan pertanian. Namun dalam pemanfaatan lahan pertanian petani di Kabupaten Indramayu masih memerlukan arahan dalam penggunaan lahan yang tepat karena perilaku petani yang belum memperhatikan kesesuaian lahan dan kebijakan pemerintah tentang intensifikasi pertanian terhadap lahan sawah. Metode yang digunakan dalam penelitian ini adalah metode deskriptif kuantitatif dan menggunakan proses pencocokan (matching) data kondisi wilayah dengan kriteria kelas kesesuaian lahan yang disusun dengan Arc GIS 10.3. Adapun parameter yang diamati adalah karakteristik wilayah (iklim, kesuburan tanah dan topografi) dan kriteria pertanian berlanjutan (ketersediaan air) untuk tanaman padi. Tujuan dilakukannya penelitian ini adalah untuk mengetahui kesesuaian lahan dan keberlanjutan pertanian tanaman padi di Kabupaten Indramayu. Hasil
\end{abstract}


analisis kelas kesesuaian lahan tanaman padi yang berkelanjutan di Kabupaten Indramayu dengan kriteria-kriteria yang telah ditentukan, didapatkan hasil dengan luas lahan yang sangat sesuai (S1) sebesar 92.419 ha, cukup sesuai (S2) 7.654 ha, sesuai marginal (S3) 15.824 ha dan tidak sesuai $(\mathrm{N})$ seluas 0 .

Kata kunci: berkelanjutan, kesuburan tanah, ketersediaan air, padi

\section{PENDAHULUAN}

\section{Latar Belakang}

Indonesia merupakan negara tropis dan mempunyai banyak sumber daya alam untuk memenuhi kebutuhan masyarakat seperti lahan pertanian. Jawa Barat dikenal sebagai daerah yang berperan penting dalam produksi tanaman padi di Indonesia, di mana pada tahun 2018, luas panen padi 1.691 .725 ha, dengan produksinya 9.539.330 ton (BPS, 2019). Kabupaten Indramayu merupakan salah satu wilayah Jawa Barat yang mempunyai sumber daya lahan pertanian yang luas seperti halnya lahan persawahan. Kabupaten Indramayu memiliki luas lahan 209.942 ha. Terdiri atas 115.897 ha lahan sawah $(55,20 \%)$, lahan bukan sawah 56.937 ha $(27,12 \%)$, dan lahan bukan pertanian 37.108 ha $(17,68 \%)$ (BPS, 2017). Namun dalam pemanfaatan penggunaan lahan pertanian petani di Kabupaten Indramayu masih memerlukan arahan dalam penggunaan lahan yang tepat, karena perilaku petani yang belum memperhatikan kesesuaian lahan dan kebijakan pemerintah tentang intensifikasi pertanian.

Bertambahnya jumlah penduduk maka dalam penggunaan lahan pertanian akan mengalami peningkatan yang disebabkan meningkatnya kebutuhan pangan. Tanaman yang banyak di kembangkan di Indramayu seperti tanaman padi. Varietas padi yang banyak di tanam di Kabupaten Indramayu yaitu varietas Ciherang, Mekongga dan Inpari. Kabupaten Indramayu dijuluki sebagai lumbung padi nya Jawa Barat. Kabupaten Indramayu menghasilkan produksi tanaman padi pada tahun 2016 mencapai 1.800 .443 ton, namun di tahun 2017 hasil produksi tanaman padi ini mengalami penurunan menjadi 1.394.771 ton. Terjadinya penurunan produksi tanaman pangan tersebut disebabkan oleh penurunan produktivitas lahan pertanian. Di mana lahan pertanian mempunyai batasan dalam penggunaannya dan masing-masing memiliki potensi dan keterbatasan dalam pengolahannya. Menurunya lahan pertanian perlu adanya identifikasi lahan untuk mengetahui kemampuan lahan dalam kegiatan pertanian. Analisis kesesuaian lahan merupakan persyaratan untuk mengelolah produksi tanaman yang berkelanjutan. Menurut Abushnaf, dkk., (2013), penentuan kesesuaian lahan untuk tanaman pertanian tertentu membutuhkan pertimbangan banyak kriteria. Salah satu kriteria untuk kesesuaian lahan yang potensial ialah seperti bahan organik, unsur hara NPK (Widiatmaka, dkk., 2016). Namun dalam penelitian ini penentuan kesesuaian lahan terdiri dari kriteria iklim, ketersediaan air, topografi dan kesuburan tanah.

Oleh karena itu, dilakukan penelitian analisis kesesuaian lahan tanaman padi yang berkelanjutan di Kabupaten Indramayu serta pengembangan dan penerapan teknologi dengan pengindraan jauh tersebut dapat meningkatkan hasil produksi pertanian pada komoditas tanaman padi. Pengindraan jauh adalaj salah satu teknologi yang paling mudah untuk keperluan di bidang pertanian yaitu membuat peta lanskap agroekologi (Weiss, dkk., 2020). Sehingga petani di Kabupaten Indramayu dapat memanfaatkan lahan pertanian dengan tepat setelah mengetahui peta kesesuaian lahan untuk komoditas padi.

\section{Tujuan}

Tujuan dilakukannya penelitian ini adalah untuk menganalisis kesesuaian lahan dan keberlanjutan lahan pertanian di 
Kabupaten Indramayu untuk komoditas tanaman padi.

\section{METODE PENELITIAN}

\section{Waktu dan Tempat Penelitian}

Penelitian dilaksanakan di Kabupaten Indramayu Provinsi Jawa Barat pada bulan Juli 2019.

\section{Alat dan Bahan Penelitian}

Pada penelitian ini digunakan alat dan berbagai data guna mendukung kegiatan penelitian, peralatan dan data tersebut adalah:

1. Data primer dilakukan pengambilan sampel tanah terdiri dari 3 jenis tanah (aluvial, podsolik, dan grumosol) dengan 3 ulangan, sehingga didapatkan 9 sampel tanah yang akan dianalisis di laboratorium untuk mengetahui kesuburan tanah

2. Data sekunder terdiri dari data administrasi, jenis tanah, jaringan irigasi, tata guna lahan dan iklim 10 tahun terakhir (2008 sampai 2017).

3. Seperangkat PC (Personal Computer) dengan menggunakan perangkat lunak (Software) pengolah data Microsoft excel dan Arc GIS 10.3 yang dikembangkan oleh ESRI (Environment Science \& Research Institute).

\section{Metode}

Metode yang digunakan dalam penelitian ini adalah metode deskriptif kuantitatif. Deskriptif yaitu menjelaskan dan mendeskripsikan data hasil pengukuran dan pengamatan yang telah diukur di lapangan maupun yang dianalisis di laboratorium. Metode kuantitatif dapat diartikan sebagai suatu cara yang digunakan untuk menjawab masalah penelitian yang berkaitan dengan data berupa angka dan program statistik. Penelitian ini dilaksanakan melalui beberapa tahap metode, yaitu:

\section{Pengumpulan Data}

Pada tahapan ini pengumpulan data diantaranya data informasi yang dibutuhkan dalam penelitian ini yang terdiri dari data primer dan sekunder. Data primer ialah untuk mengetahui kesuburan tanah dengan pengambilan 3 sampel jenis tanah yang di analisis di laboratorium untuk hasilnya dapat ditunjukkan pada Tabel 4 dan data sekunder berupa data iklim, jaringan irigasi, topografi, peta jenis tanah dan peta tataguna lahan.

2. Analisis Kondisi Fisik Kabupaten Indramayu

Analisis kondisi fisik Kabupaten Indramayu meliputi iklim (curah hujan, temperatur, dan kelembaban), topografi (kemiringan dan ketinggian), jaringan, irigasi dan jenis tanah dengan melakukan analisis spasial melalui overlay peta untuk identifikasi kesesuaian

3. Klasifikasi Kelas Kesesuaian Lahan

Evalusai kesesuaian lahan yang digunakan mengacu pada sistem klasifikasi lahan yang dikembangkan oleh Permentan no. 79 tahun 2013 tentang pedoman kesesuaian lahan pada komoditas tanaman pangan, dengan kriteria-kriteria kesesuaian lahan untuk komoditas tanaman padi.

4. Penentuan Kesesuaian Iklim, Kesuburan Tanah dan Topografi.

Penentuan tingkat kesesuaian lahan untuk lahan irigasi dan tadah hujan terdiri dari 12 variabel pembatas yaitu yaitu temperatur curah hujan, kelembaban, tekstur, nilai KTK, $\mathrm{pH}$ tanah, C-organik tanah, unsur hara $\mathrm{N}$ total, unsur $\mathrm{P}\left(\mathrm{P}_{2} \mathrm{O}_{5}\right)$, unsur $\mathrm{K}\left(\mathrm{K}_{2} \mathrm{O}\right)$, lereng dan bahaya erosi.

Tingkat kesesuaian iklim (curah hujan, temperatur dan kelembaban didasarkan dari data sekunder rata-rata selama 10 tahun pengamatan (2008-2017) di Kabupaten Indramayu.

5. Kriteria Kelas Kesesuaian Lahan

Kriteria kelas kesesuaian untuk tanaman padi lahan irigasi mengacu pada Permentan no. 79 tahun 2013 dan padi lahan tadah hujan mengacu pada Permentan no. 79 tahun 2013 ditunjukkan pada Tabel 1 dan 2. Selanjutnya dihubungkan dengan lahan pertanian berkelanjutan yang mengacu pada Permentan no. 07 tahun 2012 ditunjukkan pada Tabel 3. 
Tabel 1. Kriteria Kesesuaian Lahan Komoditas Tanaman padi (Oryza sativa) Irigasi

\begin{tabular}{|c|c|c|c|c|}
\hline \multirow{2}{*}{$\begin{array}{l}\text { Persyaratan Penggunaan/ } \\
\text { Karakteristik lahan }\end{array}$} & \multicolumn{4}{|c|}{ Kelas Kesesuaian Lahan } \\
\hline & S1 & S2 & S3 & $\mathrm{N}$ \\
\hline \multicolumn{5}{|l|}{ Temperatur (tc) } \\
\hline Temperatur rata-rata $\left({ }^{\circ} \mathrm{C}\right)$ & $24-29$ & $22-24$ & $18-22$ & $<18$ \\
\hline Ketersediaan air (wa) & Irigasi & Irigasi & Irigasi & \\
\hline Kelembaban (\%) & $30-90$ & $30-33$ & $\begin{array}{l}<30 \\
>90\end{array}$ & - \\
\hline Kelas Tekstur & halus, agak halus & sedang & agak kasar & kasar \\
\hline \multicolumn{5}{|l|}{ Retensi hara (nr) } \\
\hline KTK tanah $(\mathrm{cmol} / \mathrm{kg})$ & $>16$ & $5-16$ & $<5$ & - \\
\hline \multirow{2}{*}{$\mathrm{pH} \mathrm{H} \mathrm{H}_{2} \mathrm{O}$} & $5,5-7,0$ & $4,5-5,5$ & $<4,5$ & - \\
\hline & & $7,0-8,0$ & $>8,0$ & \\
\hline C-Organik & $>1,2$ & $0,8-1,2$ & $<0,8$ & - \\
\hline \multicolumn{5}{|l|}{ Hara tersedia (nr) } \\
\hline $\mathrm{N}$ total $(\%)$ & sedang & rendah & sangat rendah & - \\
\hline $\mathrm{P}_{2} \mathrm{O}_{5}(\mathrm{mg} / 100 \mathrm{~g})$ & tinggi & sedang & rendah-sangat rendah & - \\
\hline $\mathrm{K}_{2} \mathrm{O}(\mathrm{mg} / 100 \mathrm{~g})$ & sedang & rendah & sangat rendah & - \\
\hline \multicolumn{5}{|l|}{ Bahaya longsor (eh) } \\
\hline Lereng $(\%)$ & $<3$ & $3-8$ (diteras) & $8-30$ (diteras) & $>30$ \\
\hline Bahaya longsor & sangat ringan & ringan & sedang & berat \\
\hline
\end{tabular}

Sumber: Permentan no. 79 tahun 2013

Keterangan: S1 = sangat sesuai, $\mathrm{S} 2$ = cukup sesuai, $\mathrm{S} 3$ = sesuai marginal, $\mathrm{N}=$ tidak sesuai, $(-)$ = tidak diperhitungkan

Tabel 2. Kriteria Kesesuaian Lahan Komoditas Tanaman padi (Oryza sativa) Tadah Hujan

\begin{tabular}{|c|c|c|c|c|}
\hline \multirow{2}{*}{$\begin{array}{l}\text { Persyaratan Penggunaan/ } \\
\text { Karakteristik lahan }\end{array}$} & \multicolumn{4}{|c|}{ Kelas Kesesuaian Lahan } \\
\hline & $\mathrm{S} 1$ & $\mathrm{~S} 2$ & S3 & $\mathrm{N}$ \\
\hline \multicolumn{5}{|l|}{ Temperatur (tc) } \\
\hline Temperatur rata-rata $\left({ }^{\circ} \mathrm{C}\right)$ & $24-29$ & $22-24$ & $18-22$ & $<18$ \\
\hline \multicolumn{5}{|l|}{ Ketersediaan air (wa) } \\
\hline Curah Hujan (mm/bulan) & $175-500$ & $500-650 / 125-175$ & $650-750 / 100-125$ & $>750 /$ \\
\hline \multirow[t]{2}{*}{ Kelembaban $(\%)$} & $30-90$ & $30-33$ & $<30$ & $<100$ \\
\hline & & & $>90$ & - \\
\hline Kelas Tekstur & halus, agak halus & sedang & agak kasar & kasar \\
\hline \multicolumn{5}{|l|}{ Retensi hara (nr) } \\
\hline KTK tanah $(\mathrm{cmol} / \mathrm{kg})$ & $>16$ & $5-16$ & $<5$ & - \\
\hline \multirow[t]{2}{*}{$\mathrm{pH} \mathrm{H} \mathrm{H}_{2} \mathrm{O}$} & $5,5-7,0$ & $4,5-5,5$ & $<4,5$ & - \\
\hline & & $7,0-8,0$ & $>8,0$ & \\
\hline C-Organik & $>1,2$ & $0,8-1,2$ & $<0,8$ & - \\
\hline \multicolumn{5}{|l|}{ Hara tersedia (nr) } \\
\hline $\mathrm{N}$ total $(\%)$ & sedang & rendah & sangat rendah & - \\
\hline $\mathrm{P}_{2} \mathrm{O}_{5}(\mathrm{mg} / 100 \mathrm{~g})$ & tinggi & sedang & rendah-sangat rendah & - \\
\hline $\mathrm{K}_{2} \mathrm{O}(\mathrm{mg} / 100 \mathrm{~g})$ & sedang & rendah & sangat rendah & - \\
\hline \multicolumn{5}{|l|}{ Bahaya longsor (eh) } \\
\hline Lereng $(\%)$ & $<3$ & $3-8$ (diteras) & $8-30$ (diteras) & $>30$ \\
\hline Bahaya longsor & sangat ringan & ringan & sedang & berat \\
\hline
\end{tabular}

Sumber: Permentan no. 79 tahun 2013

Keterangan: $\mathrm{S} 1$ = sangat sesuai, $\mathrm{S} 2=$ cukup sesuai, $\mathrm{S} 3=$ sesuai marginal, $\mathrm{N}=$ tidak sesuai, $(-)=$ tidak diperhitungkan 
Tabel 3. Kriteria Lahan Pertanian Pangan Berkelanjutan

\begin{tabular}{|c|c|}
\hline Kriteria & Parameter \\
\hline $\begin{array}{lcc}\text { Potensi } & \text { Teknis } & \text { dan } \\
\text { Kesesuaian Lahan } & \end{array}$ & $\begin{array}{l}\text { a. Berdasarkan potensi teknis dan kesesuaian lahan untuk pertanian pangan } \\
\text { pokok diatur sebagai berikut: } \\
\text { - Semua lahan beririgasi dapat ditetapkan sebagai Lahan Pertanian } \\
\text { Pangan Berkelanjutan; } \\
\text { - Lahan tidak beririgasi dapat ditetapkan sebagai Lahan Pertanian Pangan } \\
\text { Berkelanjutan dengan memperhatikan besaran curah hujan tahunan } \\
\text { minimal } 1000 \text { (seribu) mm/tahun. } \\
\text { b. Tersedia minimal cukup unsur hara makro yang dibutuhkan oleh tanaman } \\
\text { pangan pokok sesuai dengan peraturan perundang-undangan. }\end{array}$ \\
\hline
\end{tabular}

Sumber: Permentan no. 07 tahun 2012

Tabel 4. Hasil Analisis Uji Tanah

\begin{tabular}{llll}
\hline \multicolumn{1}{c}{ Parameter } & \multicolumn{2}{c}{ Jenis Tanah } \\
\cline { 2 - 4 } & Aluvial & Podsolik & Grumosol \\
\hline $\mathrm{pH} \mathrm{H} \mathrm{H}_{2} \mathrm{O}$ & 6,0 & 6,6 & 6,9 \\
$\mathrm{C}$-organik & $0,94 \%$ & $1,2 \%$ & $0,82 \%$ \\
$\mathrm{~N}$ total & $0,16 \%$ & $0,16 \%$ & $0,13 \%$ \\
$\mathrm{P}$ tersedia & $39 \mathrm{ppm}$ & $19 \mathrm{ppm}$ & $19 \mathrm{ppm}$ \\
$\mathrm{K}$ & $0,56 \mathrm{me} .100 \mathrm{~g} \mathrm{~g}^{-1}$ & $0,26 \mathrm{me} .100 \mathrm{~g}^{-1}$ & $0,10 \mathrm{me} .100 \mathrm{~g}-1$ \\
Nilai KTK & $41,56 \mathrm{me}^{-1} 100 \mathrm{~g} \mathrm{~g}^{-1}$ & $38,52 \mathrm{me}^{-1} 100 \mathrm{~g}^{-1}$ & $41,77 \mathrm{me} .100 \mathrm{~g}^{-1}$ \\
Tekstur & Liat & Liat & Liat \\
\hline
\end{tabular}

Sumber: Data analisis (2019)

6. Pembuatan Peta Kesesuaian Lahan

Pembuatan peta kesesuaian lahan untuk tanaman padi dilakukan menggunakan metode aplikasi Arc GIS 10.3 yang dikembangkan oleh ESRI (Environment Science \& Research Institute). Pembuatan peta kesesuaian lahan dilakukan dengan penggabungan atau (overlay) antara beberapa kriteria, seperti kriteria ketersediaan air dengan iklim dan kriteria kesuburan tanah. Kesesuaian lahan dan kriteria pertanian berkelanjutan ditentukan dengan cara skoring dan ditentukan dengan 4 kelas, yaitu kelas S1 (sangat sesuai), S2 (cukup sesuai), S3 (sesuai marginal) dan N (tidak sesuai) yang telah ditetapkan oleh Permentan no. 79 tahun 2013 dan Permentan no. 07 tahun 2012.

\section{HASIL DAN PEMBAHASAN}

Secara umum, Kabupaten Indramayu memiliki luas sekitar 209.942 ha dan memiliki 31 kecamatan. Dengan tingkat kemiringan $0-2 \%$ (datar atau landai). Berdasarkan Gambar 1, Kabupaten Indramayu memiliki tiga jenis tanah mempunyai yaitu aluvial, podsolik dan grumosol. Sedangkan tekstur tanah didominasi oleh liat. Iklim curah hujan pada tahun 2017 sebesar $1.683 \mathrm{~mm} /$ tahun dan temperatur sekitar $22,9^{\circ} \mathrm{C}-30^{\circ} \mathrm{C}$.

\section{Kesuburan Tanah}

Tanah merupakan suatu media bagi tanaman yang bermanfaat untuk ekologis dan biologis didalam suatu lahan pertanian. Kesuburan tanah sangat berpengaruh bagi pertumbuhan dan produktivitas tanaman pangan. Kabupaten Indramayu memiliki 3 jenis tanah, yaitu jenis tanah jenis tanah aluvial, podsolik dan grumosol. Hasil uji tanah yang didapatkan di Kabupaten Indramayu dapat ditunjukkan pada Tabel 4.
Aluvial
Tanah aluvial merupakan tanah muda yang berasal dari hasil pengendapan. Tanah aluvial yang terdapat di Kabupaten Indramayu sekitar $71 \%$ atau dengan luas lahan sekitar 149.872 ha dapat ditunjukkan pada Tabel 5 dan Gambar 1. Tanah aluvial yang dijumpai di lokasi penelitian memiliki warna coklat gelap dan coklat tua atau kelabu. Sifat tanah aluvial berdasarkan 
pengamatan dan analisis memiliki tekstur pasir $6 \%$, debu $28 \%$ dan $66 \%$, kemudian memiliki nilai bahan organik 0,94\%, sementara unsur $\mathrm{N}$ yaitu $0,16 \%$, Nilai P 39 ppm dan nilai $\mathrm{K}$ sebesar $0,56 \mathrm{me} .100 \mathrm{~g}^{-1}$, dapat ditunjukkan pada Tabel 4 dan dari analisis tersebut, dapat dikatakan kondisi tanah dikategorikan agak kritis karena corganik dan unsur hara lainnya sangat rendah.

\section{Podsolik}

Tanah Podsolik adalah tanah yang berordo Ultisol. Tanah podsolik yang tersebar di Kabupaten Indramayu sekitar $21 \%$ atau dengan luas sekitar 44.032 ha dapat ditunjukkan pada Tabel 5 dan Gambar 1. Tanah podsolik yang dijumpai dilokasi penelitian memiliki warna merah hingga kuning. Sifat tanah podsolik berdasarkan analisis dan pengamatan memiliki tekstur pasir $8 \%$, debu $26 \%$ dan $66 \%$, kemudian memiliki nilai bahan organik $1,2 \%$, sementara unsur $\mathrm{N}$ yaitu $0,16 \%$, Nilai $\mathrm{P} 19$ ppm dan nilai $\mathrm{K}$ sebesar $0,26 \mathrm{me} .100 \mathrm{~g}^{-1}$, dapat ditunjukkan pada Tabel 4 dan dari analisis tersebut maka kondisi tanah berkategori agak kritis.

\section{Grumasol}

Tanah grumosol yang tersebar di Kabupaten Indramayu sekitar $8 \%$ atau dengan luas sekitar 16.033 ha dapat ditunjukkan pada Tabel 5 dan Gambar 1. Kabupaten Indramayu tanah grumosol tersebar di 4 kecamatan, yaitu kecamatan Gantar, Terisi, Cikedung, Lelea, Bangodua dan Widasari. Tanah grumosol yang dijumpai pada lokasi penelitian memiliki warna keabu-abuan hingga hitam. Sifat tanah grumosol berdasarkan pengamatan memiliki tekstur pasir $22 \%$, debu $31 \%$ dan $47 \%$, kemudian memiliki nilai bahan organik $0,82 \%$, sementara untuk unsur $\mathrm{N}$ yaitu $0,13 \%$, Nilai P 19 ppm dan nilai K sebesar 0,10 me.100g-1, dapat ditunjukkan pada Tabel 4 dan dari analisis tersebut maka dapat dikatakan kondisi tanah tersebut memang miskin unsur hara, dilihat dari analisis c-organik dari tanah tersebut mendapatkan hasil yang paling rendah dari jenis tanah lainnya.

Tabel 5. Jenis Tanah di Kabupaten Indramayu

\begin{tabular}{cccc}
\hline No & Jenis Tanah & Luas (ha) & Persen (\%) \\
\hline 1. & Aluvial & 149872 & 71 \\
2. & Podosolik & 44032 & 21 \\
3. & Grumosol & 16033 & 8 \\
\hline & Total & 209937 & 100 \\
\hline
\end{tabular}

Sumber: Analisis data (2019)

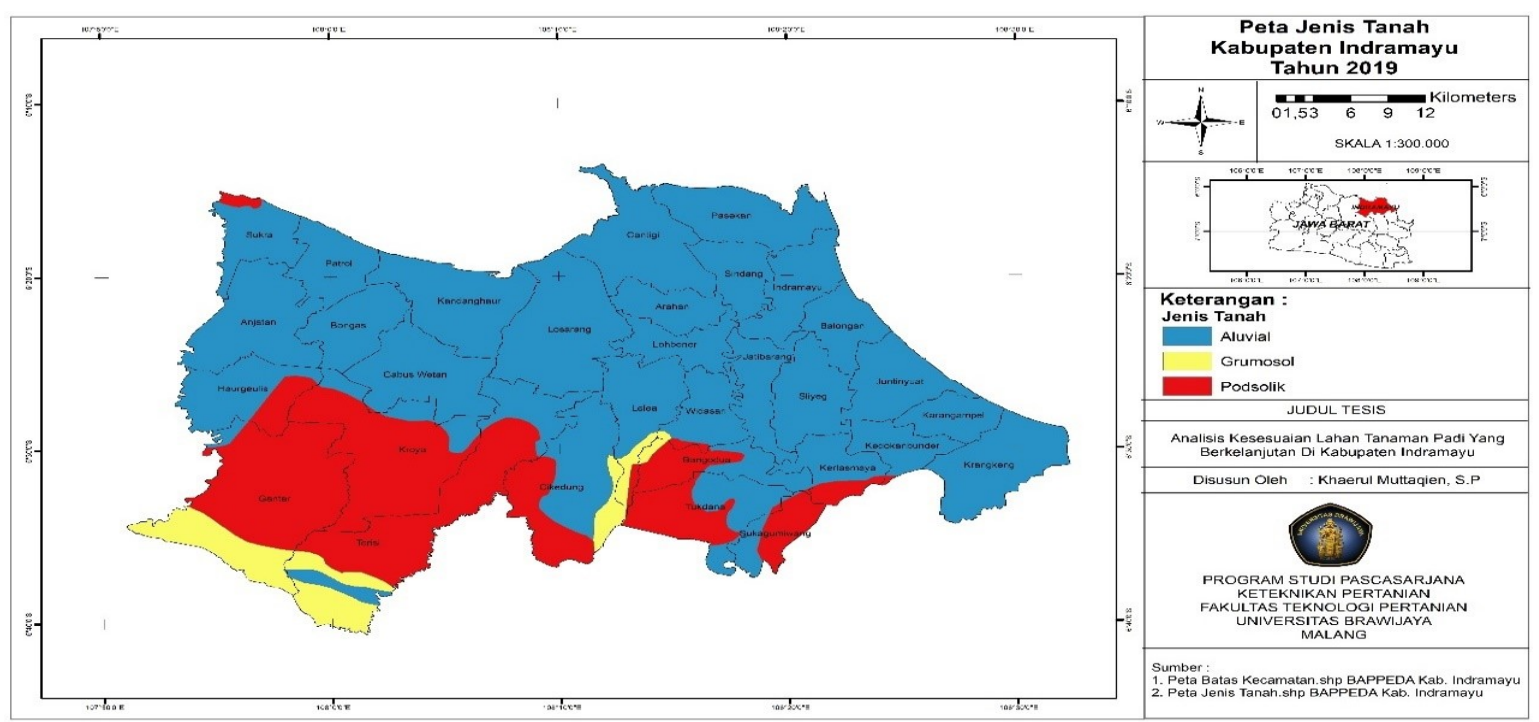

Gambar 1. Jenis Tanah di Kabupaten Indramayu 


\section{Ketersediaan Air}

Ketersediaan air merupakan suatu kemampuan tanah untuk menyediaakan air untuk memenuhi kebutuhan air tanaman melalui irigasi maupun air tanah. Kapasitas air yang tersedia ditanah bervariasi berdasarkan kedalaman tanah, tekstur tanah, kandungan organik dan anorganik tanah (Seyedmohammadi, dkk., 2019). Pada lahan penelitian di Kabupaten Indramayu terdapat luasan lahan yang menggunakan irigasi yaitu sebesar 92.419 ha, dan lahan yang masih menggunakan atau sebagai lahan tadah hujan yaitu sekitar 23.478 ha ditunjukkan pada Tabel 6 dan Gambar 2.

Saragih, dkk., (2014), menyatakan bahwa peran irigasi dalam lahan pertanian sebagai salah satu sarana utama dalam mempertahankan swasembada beras. Produksi pertanian pada lahan kering dan semi kering biasanya membutuhkan irigasi dan lahan pertanian menggunakan air sekitar 80\% hingga 95\% (Ma, dkk., 2018). Kabupaten Indramayu sendiri merupakan bagian dari wilayah yang dikatakan sebagai lumbungnya padi di Jawa Barat, karena para petani di Indramayu mayoritas lahannya di tanam padi. Lahan irigiasi dapat ditanam hingga 2 kali dalam satu tahun untuk tanaman padi. Apabila intensitas tanam padi dilakukan 3 kali dalam setahun akan beresiko terhadap perkembangan hama dan penyakit. Dalam meningkatkan produktivitas lahan irigasi sangat berperan penting dalam meningkatkan hasil tanaman padi. Lahan yang memiliki jaringan irigasi dapat meningkatkan produktivitas tanaman dari tahun ke tahun karena irigasi mampu mengatasi masalah di musim kemarau.

Tabel 6. Ketersediaan Air di Kabupaten Indramayu

\begin{tabular}{cccc}
\hline No & Ketersediaan Air & Luas (ha) & Persen (\%) \\
\hline 1. & Irigasi & 92419 & 79,7 \\
2. & Tadah Hujan & 23478 & 20,3 \\
\hline & Total & 115897 & 100,0 \\
\hline
\end{tabular}

Sumber: Analisis data (2019)

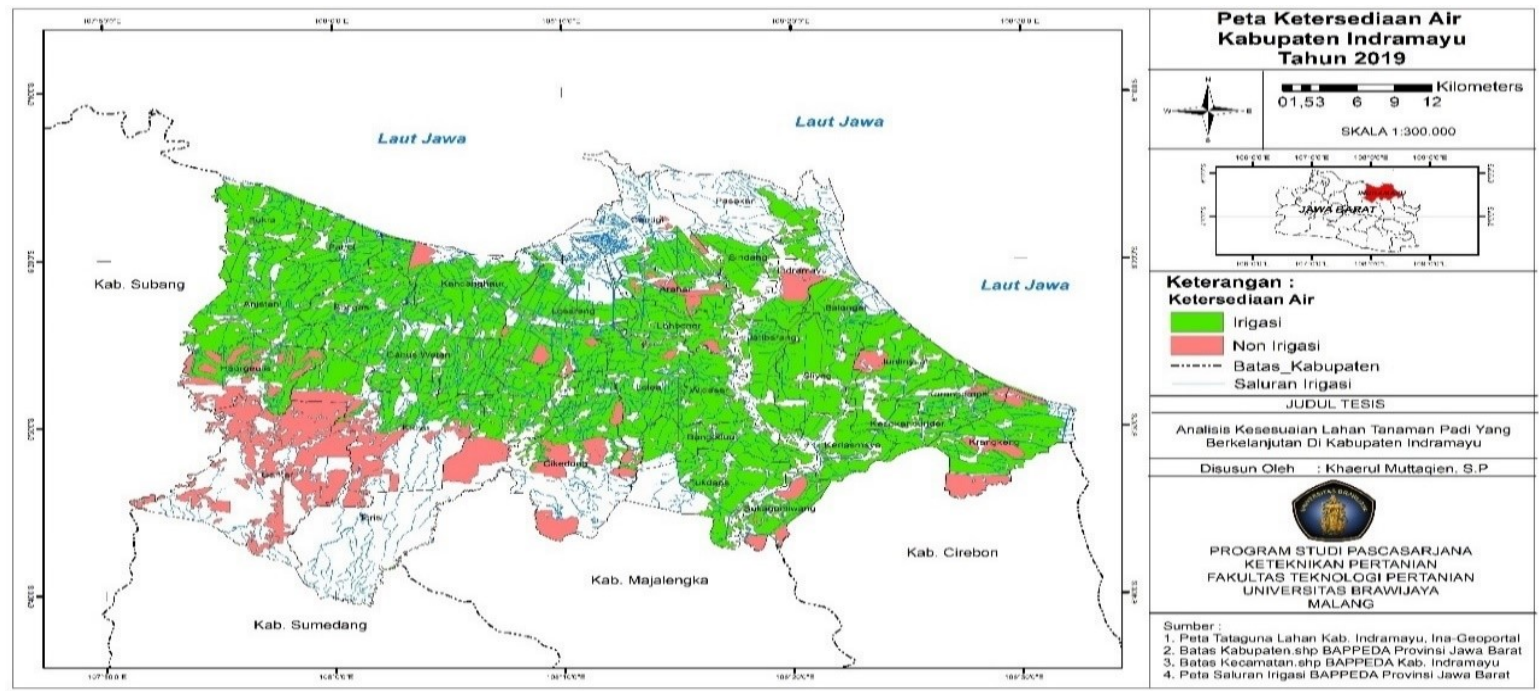

Gambar 2. Ketersediaan Air di Kabupaten Indramayu

Proses evalusai lahan untuk menentukan kelas kesesuaian lahan yang didasarkan atas karakteristik lahan dan dihubungkan dengan keberlanjutan lahan pertanaian untuk tanaman pangan maka dilakukan penggabungan (overlay) dan analisis spasial. Dari hasil penggabungan dan analisis spasial ditentukan faktor pembatas yang dapat memengaruhi lahan pertanian untuk komoditas padi yang berkelanjutan. Gambar 3 memperlihatkan peta kelas kesesuaian lahan padi irigasi dan padi tadah hujan berdasarkan ketersediaan air. 
Hasil dari evaluasi lahan yang telah dilakukan, didapatkan beberapa kelas kesesuaian untuk tanaman padi untuk lahan irigasi dan lahan tadah hujan di Kabupaten Indramayu seperti disajikan pada Tabel 7. Pada kelas S1 didapatakan dengan luas lahan sekitar 92.419 ha atau sebesar 79,7\%, kelas S2 didapatkan luas lahan sekitar 7.654 ha atau sebsar 6,6\% dan kelas S3 didapatkan luas lahan 15.824 ha atau sebesar 13,7\%. Sehingga dapat dikatakan bahwa komoditas tanaman padi di Kabupaten Indramayu yang dapat berkelanjutan mencapai $80 \%$.

Tabel 7. Kelas Kesesuaian Lahan Komoditas Padi yang Berkelanjutan

\begin{tabular}{|c|c|c|c|c|}
\hline \multirow[t]{2}{*}{ Kecamatan } & \multicolumn{4}{|c|}{ Luas lahan (ha) } \\
\hline & $\mathrm{S} 1$ & S2 & S3 & $\mathrm{N}$ \\
\hline Haurgeulis & 1135 & 0 & 2843 & 0 \\
\hline Gantar & 0 & 0 & 6096 & 0 \\
\hline Kroya & 2474 & 0 & 4442 & 0 \\
\hline Gabuswetan & 5850 & 0 & 0 & 0 \\
\hline Cikedung & 3181 & 2479 & 0 & 0 \\
\hline Terisi & 3629 & 1470 & 0 & 0 \\
\hline Lelea & 4639 & 361 & 0 & 0 \\
\hline Bangodua & 3219 & 0 & 0 & 0 \\
\hline Tukdana & 3731 & 0 & 0 & 0 \\
\hline Widasari & 2856 & 0 & 0 & 0 \\
\hline Kertasmaya & 2915 & 0 & 0 & 0 \\
\hline Sukagumiwang & 1092 & 766 & 0 & 0 \\
\hline Krangkeng & 3325 & 1860 & 0 & 0 \\
\hline Karangampel & 1966 & 250 & 0 & 0 \\
\hline Kedokan Bunder & 2109 & 0 & 0 & 0 \\
\hline Juntinyuat & 3474 & 468 & 0 & 0 \\
\hline Sliyeg & 4259 & 0 & 0 & 0 \\
\hline Jatibarang & 2976 & 0 & 0 & 0 \\
\hline Balongan & 1947 & 0 & 0 & 0 \\
\hline Indramayu & 1056 & 0 & 745 & 0 \\
\hline Sindang & 2118 & 0 & 0 & 0 \\
\hline Cantigi & 1534 & 0 & 181 & 0 \\
\hline Pasekan & 878 & 0 & 0 & 0 \\
\hline Lohbener & 2447 & 0 & 107 & 0 \\
\hline Arahan & 1780 & 0 & 679 & 0 \\
\hline Losarang & 5302 & 0 & 423 & 0 \\
\hline Kandanghaur & 5857 & 0 & 308 & 0 \\
\hline Bongas & 3930 & 0 & 0 & 0 \\
\hline Anjatan & 6100 & 0 & 0 & 0 \\
\hline Sukra & 3445 & 0 & 0 & 0 \\
\hline Patrol & 3195 & 0 & 0 & 0 \\
\hline Total & 92419 & 7654 & 15824 & 0 \\
\hline
\end{tabular}

Sumber: Analisis data (2019)

Dalam menentukan kelas kesesuaian tanaman yang berkelanjutan ditentukan oleh ketersediaan air seperti lahan irigasi dan lahan tadah hujan untuk tanaman pangan. Pada tanaman padi yang ditunjukkan pada (Gambar 3) memiliki tiga kelas kesesuaian lahan yang dapat dikatakan berkelanjutan yaitu pada kelas S1 hampir seluruh Kabupaten Indramayu dapat dikatakan sangat sesuai karena di setiap kecamatan mempunyai jaringan irigasi masing-masing, namun hanya pada satu kecamatan yaitu kecamatan Gantar seluruhnya masih mengandalkan ketersediaan air nya dengan curah hujan. Untuk kelas kesesuaian S2 pada tanaman padi dengan lahan tadah hujan sebagian lahannya didapat di kecamatan Terisi, Cikedung, Krangkeng, Sukagumiwang, Karangampel, Juntinyuat dan Lelea. Dan untuk kategori kelas kesesuaian lahan S3 (Sesuai Marginal) sebagian lahannya terdapat di kecamatan 


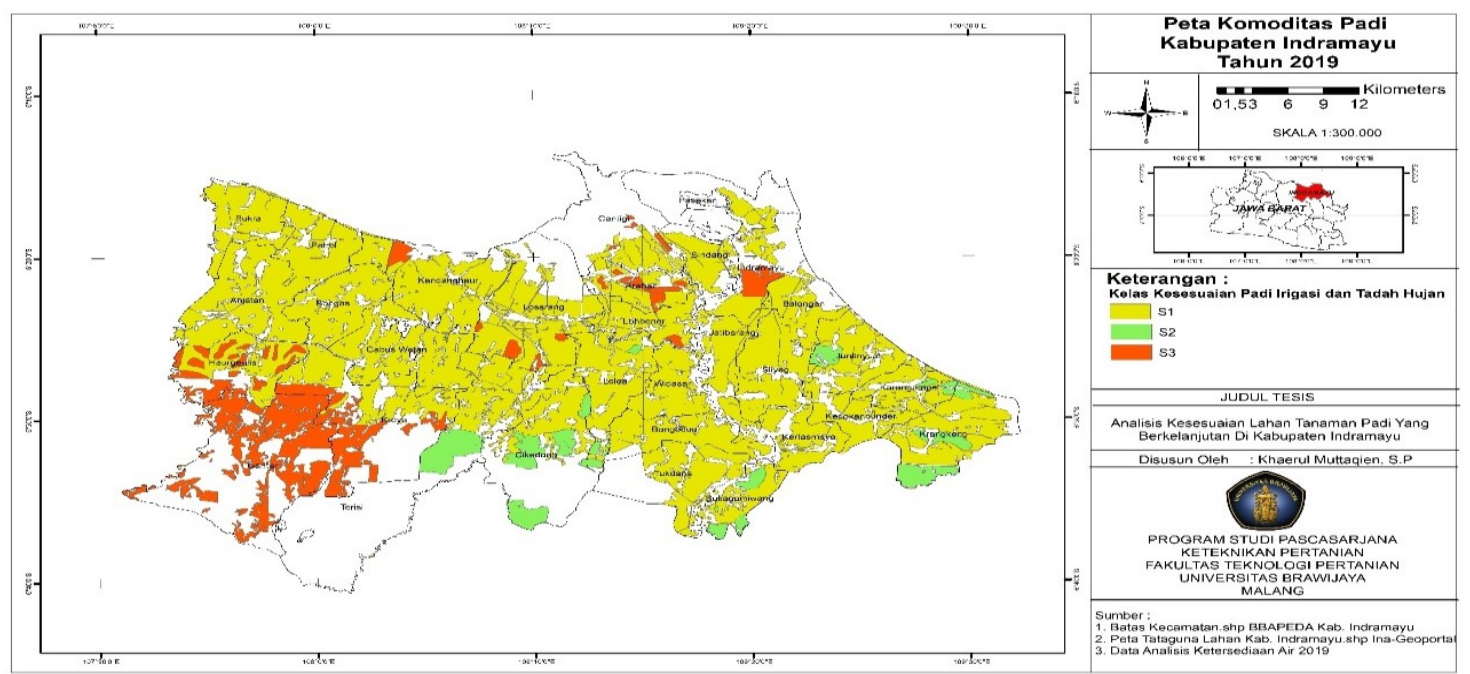

Gambar 3. Peta Kesesuaian Lahan Tanaman Padi Berdasarkan Ketersediaan Air

Tabel 8. Nilai Curah Hujan Bulanan dan Curah Hujan Tahunan

\begin{tabular}{|c|c|c|c|}
\hline No & Kecamatan & $\begin{array}{c}\mathrm{mm} / \\
\text { bulan }\end{array}$ & $\begin{array}{l}\mathrm{mm} / \\
\text { tahun }\end{array}$ \\
\hline 1 & Haurgeulis & 102 & 1224 \\
\hline 2 & Gantar & 102 & 1224 \\
\hline 3 & Kroya & 118 & 1413 \\
\hline 4 & Gabuswetan & 115 & 1373 \\
\hline 5 & Cikedung & 126 & 1508 \\
\hline 6 & Terisi & 124 & 1490 \\
\hline 7 & Lelea & 125 & 1498 \\
\hline 8 & Bangodua & 129 & 1546 \\
\hline 9 & Tukdana & 132 & 1582 \\
\hline 10 & Widasari & 124 & 1508 \\
\hline 11 & Kertasmaya & 136 & 1632 \\
\hline 12 & Sukagumiwang & 133 & 1589 \\
\hline 13 & Krangkeng & 140 & 1674 \\
\hline 14 & Karangampel & 140 & 1674 \\
\hline 15 & Kedokan Bunder & 140 & 1674 \\
\hline 16 & Juntinyuat & 140 & 1674 \\
\hline 17 & Sliyeg & 139 & 1671 \\
\hline 18 & Jatibarang & 124 & 1483 \\
\hline 19 & Balongan & 134 & 1655 \\
\hline 20 & Indramayu & 120 & 1440 \\
\hline 21 & Sindang & 120 & 1434 \\
\hline 22 & Cantigi & 120 & 1434 \\
\hline 23 & Pasekan & 120 & 1434 \\
\hline 24 & Lohbener & 120 & 1434 \\
\hline 25 & Arahan & 120 & 1434 \\
\hline 26 & Losarang & 122 & 1474 \\
\hline 27 & Kandanghaur & 115 & 1407 \\
\hline 28 & Bongas & 102 & 1224 \\
\hline 29 & Anjatan & 102 & 1224 \\
\hline 30 & Sukra & 102 & 1224 \\
\hline 31 & Patrol & 102 & 1224 \\
\hline
\end{tabular}

Sumber: Analisis data (2019)
Gantar, Indramayu, Arahan, Cantigi, Kandanghaur, Losarang, Haurgeulis, Kroya dan Lohbener. Hal ini karena curah hujan bulanan untuk tanaman padi yang didapatkan di wilayah Kabupaten Indramayu masih memiliki nilai curah hujan di bawah kelas kesesuaian S1, yaitu dengan nilai kurang dari $175 \mathrm{~mm} / \mathrm{bulan}$ yang ditunjukkan pada Tabel 8. Kelas kesesuaian Sangat Sesuai (S1) untuk tanaman padi di Kabupaten Indramayu sekitar 92.419 ha atau 79,7\%. Kelas kesesuaian Cukup Sesuai (S2) didapatkan sekitar 7.654 ha atau 6,6\% dan kelas kesesuaian Sesuai Marginal (S3) didapatkan sekitar 15.824 ha atau 13,7\%. Kelas kesesuaian lahan S3 dengan mayoritas terluas didapatkan pada kecamatan Gantar dan Kroya dapat ditunjukkan pada Gambar 3.

\section{KESIMPULAN DAN SARAN}

\section{Kesimpulan}

Hasil analisis kelas kesesuaian lahan tanaman padi yang berkelanjutan di Kabupaten Indramayu dengan kriteria iklim, ketersediaan air, topografi dan kesuburan tanah didapatkan hasil dengan luas lahan total kelas S1 (sangat sesuai) sebesar 92.419 ha, terdapat di 30 kecamatan kecuali kecamatan Gantar. Kelas S2 (cukup sesuai) sebesar 7.654 ha, terdapat di kecamatan Cikedung, Terisi, Lelea, Sukagumiwang, Krangkeng, Karangampel dan Juntinyuat. 
Kelas S3 (sesuai marginal) sebesar 15.824 ha, terdapat di kecamatan Haurgeulis, Gantar, Kroya, Indramayu, Cantigi, Lohbener, Arahan, Losarang, Kandanghaur dan kelas $(\mathrm{N})$ sebesar 0 .

\section{Saran}

Di Kecamatan Gantar ketersediaan airnya masih mengandalkan air hujan, namun belum memenuhi kriteria klasifikasi kesesuaian lahan ke dalam kelas sangat sesuai dan cukup sesuai, sehingga perlu dibuatkan jaringan irigasi untuk meningkatkan hasil produksi tanaman padi.

\section{DAFTAR REFERENSI}

Abushnaf, F.F., Spence, K.J., \& Rotherham, I.D. (2013). Developing a Land Evaluation Model for the Benghazi Region in Northeast Libya using a Geographic Information System and Multi-criteria Analysis. $A P C B E E$ Procedia, 5(13), 69-75.

Badan Pusat Statistik. (2017). Kabupaten Indramayu dalam Angka 2017. BPS Kabupaten Indramayu.

Badan Pusat Statistik. (2019). Provinsi Jawa Barat dalam Angka 2019. BPS Provinsi Jawa Barat.

Ma, Y., Liu, S., Song, L., Xu, Z., Liu, Y., $\mathrm{Xu}, \mathrm{T}$., \& Zhu, Z. (2018). Estimation of Daily Evapotranspiration and
Irrigation Water Efficiency at a Landsat-like Scale for an Arid Irrigation Area using Multi-source Remote Sensing Data. Remote Sensing of Environment, 216(18), 715-734.

Saragih, D. N. S., Sumono \& Ichwan, N. (2014). Kajian Potensi Produksi Padi Pada Lahan Sawah Irigasi Di Kabupaten Deli Serdang. J. Rekayasa Pangan dan Pertanian, 2(4), 117-126.

Seyedmohammadi, J., Sarmadian, F., Jafarzadeh, A. A., \& McDowell, R. W. (2019). Development of a Model using Matter Element, AHP and GIS Techniques to Assess the Suitability of Land for Agriculture. J. Geoderma, 352(19), 80-95.

Weiss, M., Jacob, F., \& Duveiller, G. (2020). Remote Sensing for Agricultural Application: A Metreview. Remote Sensing of Environment, 236(20), 1-19.

Widiatmaka, Ambarwulan, W., Paulus B.K.S., Sabiham, S., Machfud, \& Hikmat, M. (2016). Remote Sensing and Land Suitability Analysis to Establish Local Specific Inputs for Paddy Fields in Subang, West Java. Procedia Environmental Sciences, 33(16), 94-107. 